\title{
Studies on Optimization of E-commerce Network Accounting and Finance
}

\author{
YANG Wen-chao" ${ }^{1}$ MENG Qing-hua ${ }^{2}$ \\ 1. School of Management, Xuzhou Institute of Technology, Jiangsu, Xuzhou,221008 \\ 2. Library, Xuzhou Institute of Technology, Jiangsu, Xuzhou,221008
}

Key words: network; electronic commerce; internet; accounting

\begin{abstract}
This paper studies the development of network finance and accounting from the aspects of the diversified development risk dynamic timing point and humanistic internal control, the paper built the idea of electronic commerce network accounting; aimed at the issue of accounting internationalization facing the development of electronic commerce, the issue of accounting subjects virtualization, the paper put forward the measures for the development of electronic commerce network accounting, analyzed the thought line of electronic commerce network development, and illustrated the trend of electronic commerce network accounting.
\end{abstract}

\section{Introduction}

Broadly speaking, establish a network of e-commerce technology EC (Electronic Commerce) refers to the use of computer networks and all kinds of electronic tools business and trade activities. E-commerce is the product of computer and network technology development, it is compared with the traditional business have activities across time and space and with economic and efficient features. It is a supply chain management system SCM, CRM customer relationship management systems and enterprise resource planning ERP management system in one of the business collaboration system is an integrated information technology and electronic social network economy, the high degree of modern information technology business model. E-commerce is not only for the business world, but also covers e-commerce unit of computerized accounting information system inside the various aspects of its subsystems. Today's e-commerce to promote the efficient flow and optimize the allocation of factors of production worldwide, has become the main form of business the way of the Internet age and 21st century business activities.

Network Accounting is a web-based environmental accounting information system, enterprise financial accounting business remoting support for electronic documents and electronic money, performs dynamic accounting, changes in the way financial information access and use, and become an important component of e-commerce section. Network Accounting is carried out on a variety of transactions and events recognition, measurement and disclosure of accounting activities, providing support to enhance e-commerce accounting for the high degree of development studies. Therefore, this article also covers the network accounting related content. Network Finance is the core of financial management, business management and financial management integration, network-based technology to support e-commerce, online management to achieve the financial and operational synergies, a variety of remote management operation and handling of a new financial management model.

\section{The Development concept of E-Commerce Network Accounting}

Under the new model of network management, in order to meet the requirements of economic development of Internet, e-commerce presents a wide range of financial management objectives trends. Conditions in the network should be a new way of thinking, build in line with today's e-commerce era accounting concepts:

\section{(1) Facing the dynamic time concept of risk}

Network economy is a high risk of economic operation mode. Volatile economic environment 
in the face of complex networks, the establishment of risk awareness, avoidance and control risk. E-commerce accounting system uses a real-time reporting. With the accounting entity virtualization, the company is only a temporary body, ready to disappear. At this time accounting risks in a dynamic operation will be relatively large. Therefore, to establish as soon as possible to adapt to the dynamic environment of the accounting system of accounting theory, methodology, evaluation system and respond to risk pre-control system. Accounting concepts should grasp the pulse of the dynamic point of realization in the front row in the changing accounting.

\section{(2) Grasp the concept of diversification}

Under the new model of network management, financial management objectives diversified trend. Financial management should consider a variety of factors, shoulder social responsibility, focusing on enterprise development potential and expected benefits, coordinate the interests of business or operations of the parties to achieve mutual benefit and win-win. Accounting concept embodies a sense of responsibility to achieve improved accounting diversified development.

\section{The development of e-commerce accounting issues}

\section{(1) Accounting entity virtualization issues}

Accounting entity is the object aimed at accounting services. For the traditional description of the accounting entity is a real unit body. In the e-business process, prompting the body to break the traditional accounting entity spatial expansion into the world, changing the spatial characteristics of the entity body. Network of strategic alliances to make multinational companies more closely linked, so that long-range, multi-object business services for centralized financial accounting management possible. Network information flow, business flow, reducing many intermediate links, from the best operating channel to meet customer needs within the maximum range and the fastest, lowest cost access to the network in the international market. Start online banking so that the flow of funds, electronic documents clearing, logistics becomes convenient placement, showing the object of international trading, electronic trading procedures, invisible process of trading. Thus, the formation of an e-commerce network environment, will also enable virtual accounting entity came into being. Depending on the subject of virtualization accounting information users need, combined with market changes rapidly and quickly shifting alliances, or even disappear. In the age of electronic commerce, network virtualization accounting body in a fuzzy state, these virtual online businesses, Internet businesses in the new economy form a network of economic entities, how to identify its virtual nature, it is worth pondering.

\section{(2) Accounting international development issues}

E-commerce can narrow the distance between the countries in the world, the world economy into one. In a very short period of time, to enhance the degree of capital circulation and efforts to achieve a huge amount of money in turnover over the world, accelerated capital investment and liquidity in the international arena. Enterprise standing on the international stage, to seek the storm in the international competition for survival and development, the need to have a strong foothold in the capital only, but also need to invest huge amounts of money, eliminate backward production capacity. And technology, continue to strengthen the scientific and technological research and development of new products. Where there are huge amounts of money? Only a few companies can rely on accumulation or borrowing by domestic financial institutions to support their income, and most companies need to raise international funds to develop, making an international money lending law must form. It also requires a country to lend funds to develop better credit decisions, must also credit status and financial situation of foreign borrowing units to do the investigation. E-commerce into international trade, it is necessary to understand the financial statements and the accounting system of foreign companies, require standardized financial statements in accordance with international practice and establish a uniform accounting procedures and methods. Based on the accounting problems of these values in the development of international get us thinking. 


\section{(3) The issues in Professional and technical personnel of accounting}

Accounting personnel in e-commerce activities, the corresponding requirements of high quality management personnel, both requiring them to be proficient in computer network knowledge, basic troubleshooting skills, capabilities, and basic maintenance of the computer, but also requires them to have a deep knowledge of accounting theory and skill accounting business skills. Currently, some enterprises accountants low level of technical expertise, practical ability is not strong, cannot meet the requirements of the development of e-commerce accounting, education and training needs to be improved.

\section{E-commerce web Accounting development ideas}

Business activities conducted mainly in the form of e-commerce on the Internet. Internet-based e-commerce operation, in order to adapt to this particular business model, financial management necessary to raise new ideas.

\section{(1) Adapt to e-commerce technology to improve quickness}

Network in real time accounting information are stored in a central database companies, accountants can take advantage of network information systems into accounting software, ready to form a variety of financial reports to meet the requirements of quick decision-makers of accounting information. Virtue computer powerful processing capabilities and network transmission capacity, high-tech communications and computer technology works using information users simply click of a mouse you can generate the required accounting information in a timely manner.

Accounting professionals develop e-commerce network of professional core competencies include e-business process modeling capabilities, network marketing capabilities, business website building capacity, the ability to understand business model. Demo online banking transactions, visit the e-commerce online marketing, online ordering and online transactions.

\section{(2) Training e-commerce network of accounting professionals}

Develop e-business e-commerce network of accounting professionals in professional core competencies include e-business process modeling capabilities, network marketing capabilities, business website building capacity, the ability to understand business model. Demo online banking transactions, visit the e-commerce online marketing, online ordering and online transactions. Should also learn about a new topic structure of human resource accounting, information, knowledge and pricing and other intangible assets.

\section{E-commerce development trend of network accounting}

Enterprises must improve their system functionality and improving network technology, to meet the development of e-commerce era, and in which the momentum forward.

\section{(1) Internal digital transmission standard management}

Realization of e-commerce, not only in the business of electronic trading on the outside, but also demonstrated between institutions within the various production processes or business unit supplies products such as digital transmission. Internal digital standard implementation, not only conducive to the internal system to conduct a comprehensive and scientific digital management mode, and the data it generates is also conducive to the data reference and standard external transactions accounting, improving the system of units of foreign exchange efficiency avoid unnecessary losses.

\section{(2) Raise the standard data interface technology}

Although the data in the form of the Internet are subject to WWW protocol, but its type or variety. E-commerce requires a two-way data can be independently and freely exchange with customers to achieve mutual business purpose of the transaction to obtain electronic data. It 
enhanced data sharing system resources, but also to ensure the security of data transmission resources, which is an essential factors and conditions that can be successfully implemented e-commerce.

\section{Conclusion}

Computer technology and network technology, network to e-commerce and accounting into one, forming a three-dimensional pattern of implementation of network accounting development. The development of the concept of building a network of accounting breakthrough development issues, the development of ideas and propose effective measures to improve the network technology, digital management level, expect e-commerce web development model in accordance with accounting network, intelligent, and open up new space for development.

\section{References:}

[1] Chen Yuan. Reflections on the development of network accounting[J]. Journal of Zhejiang Business Technology Institute, 2004, (1).

[2] Hu Wei. Development of the network era of computerized accounting[J]. Chinese Agricultural Accounting,2007, (4).

[3] Jia Connie, Li Zhijun, How to implement computerized accounting industrial enterprises[J]. Plains audit,2002, (8).

[4] Jiang Li. Development concepts and internal control system development and construction analysis of network accounting[J]. Knowledge Economy,2011, (10).

[5] Li Fumei. The impact of electronic commerce on financial accounting[J]. Enterprise economy,2005, (5).

[6] Wang Yihan. "Computerized Accounting" theory and method --- an urgent need to open up the field of study[J].Journal of Xiamen University (Philosophy and Social Science),1996,(3).

[7] Zhong Qi Zheng, Luo Hongke. Computerized Accounting inevitably move toward network[J]. Market Modernization,2007, (21). 